\title{
Scientia Est Potentia Welcome Words
}

\author{
Karel Večeře \\ president of the Czech Office for Surveying, Mapping and Cadastre \\ karel.vecere cuzk.cz
}

Ladies and gentlemen, distinguished guests,

It is a great honour for me to cordially greet you here in Prague on the occasion of the Knowledge is Power conference. The Symposium has been organised by the FIG Commission for professional education, and the Faculty of Civil Engineering of the Czech Technical University in Prague, and is being to mark the occasion of the 300th anniversary of its foundation. I am really pleased, that this Symposium is taking place right here in Prague and I hope that it will be a source of inspiration for the development of education in land surveying and geomatics.

Allow me now to say a couple of words from the position of the man who is responsible not only for the nation-wide land surveying activities and products (maps etc.) but also for the administration of the cadastre of real estates.

Land surveying has changed dramatically over the last 20 years. We had barely got used to electronic surveying devices, which replaced the previous optical equipment, when satellitepositioning methods arrived. Built-in computers in measuring devices process the surveying results and therefore written records of surveyed data are hardly used at all. Computer processing and presentation of the results of land surveying activities have undergone radical changes. Only the people with excellent basic knowledge acquired in the educational process can respond to these changes and can be actively engage to them. Previous technical development has brought many incentives into the educational system, the content of Surveyors' studies has been changing, and the additional education for land surveyors has been growing. New study specializations such as geomatics, which reflects this development, have appeared.

We can also recognize other aspects of this progress. We do not need so much time for surveying itself and the processing of results is also much faster. Could this be a cause for the decline in the number of surveyors? I personally don't think so. The point is, however, that surveyors should evolve into further areas. The range is really wide. We are traditionally very closely connected to informatics, and Universities have also had to revise their educational programmes as a result of this. I dare say that GIS can be studied at all Universities with the land surveying specialization.

However, GIS is not the only field for surveyors and for their potential value. The real estate market has been growing rapidly in the Czech Republic - it represents more than 10\% annual growth. It is a huge sphere for our profession. Due to our history the orientation in cadastral documentation is still very complicated and surveyors are able to assist in this, it means not only in executions of surveying sketches for partioning of parcels or surveying of 
new buildings. Despite this fact the combination of a land surveying company with a real estate agency is still rather exceptional. It might be an area for some changes in the content of educational programmes, which should enable to acquire wider knowledge in the field of evaluation of real estates or even in economy with focus on the real estate market. I think that our universities are able to prepare highly skilled graduates even in the field of land consolidation, and possibly in further fields important for cooperation on projects focused on better use of both urban and rural areas. That is the reason why surveyors often take part in teams preparing and launching such projects.

I could go on listing fields suitable for surveyors for many hours, the point is, however, whether they will get a sufficient base for these specializations during their study and whether we will be able to motivate them enough for these interdisciplinary fields.

By the end of 2006 a total of 720 graduates from technical universities focused on surveying had worked in our offices but beside them also 432 graduates from faculties of law and 343 graduates from other universities, particularly IT specialists and economists. In addition to that we employ more than 3000 alumni of secondary schools, half of them being surveyors. The great number of lawyers is a result of the fact, that we are responsible for the registration of rights to real estates. We execute legal examination of deeds about real estates and on this base we decide about the registration of the right in the cadastre of real estates or its refusal. The experts in informatics support not only everyday operation of IT but also further development of cadastral information system and other GI systems. As I have already mentioned, the cadastre of real estates in the Czech Republic includes and connects at present 3 main professions:

1. Surveyors, particularly responsible for the mapping part of the cadastre, but also supporting other technical activities,

2. Lawyers, supporting the registration of rights and supervising other administrative activities,

3. Experts in informatics, taking care of the complex databases of the territory and supporting a wide range of services for customers and employees.

The graduates of different universities have to cooperate really closely. Without such cooperation we could not achieve satisfactory results. General overview of each other's work and a certain overlap into the specialization of their colleagues gained already at university are very useful for cooperation of experts from different specializations. It seems to me, that there is no problem to provide enough education in informatics for surveyors. Universities produce graduates in surveying field who are more than just skilled users of IT and who are competent even in areas requiring deeper knowledge of informatics. It is interesting that nowadays even graduates of faculties of law have not serious problems with informatics and are able to make use of information technologies on a high level.

More complicated situations occur in the cases that require certain knowledge of law. The surveyor working in the cadastre also needs knowledge of Civil Code, Land Law, Administrative Procedures Law, Urban Planning Law and others. It is rare to find a graduate of both branches - surveying and law, but from my point of view it isn't so important. The important thing is to improve the legal awareness of surveyors during their education - at least in land, building and administrative laws. And that is not only the problem of surveyors in the state 
administration. The surveyor should be able to act as a complete advisor at least regarding the technique of real estates business. To do so, they have to have knowledge of further processes provided usually by experts from other branches such as urban planning, building proceeding, water proceeding or they need skills of some important aspects of the nature and landscape protection. Unfortunately, surveyors often acquire this necessary knowledge from their working experience, and often in a very complicated way.

It is necessary to mention, that the graduates of faculties of law face the same problem of insufficient awareness in some technical fields. It is difficult in many cases to provide them with sufficient basic technical knowledge to simplify their orientation in surveying sketches. They do not get such skills at the faculty. Nevertheless, this knowledge is the essential for correct registration of the proprietary rights, of mortgages or easements, apart from correct making a deed about the real estate. That is why we organize further education in this basic field of cadastre for our lawyers.

Ladies and Gentlemen, I have tried to address the problems faced by state administration responsible for cadastre of real estates and surveying in connection with university education. We realize more than 1,5 mil. registrations of changes into the cadastre, introduce 130 thousand survey sketches into maps and update other geographical documentation of the $\mathrm{CZ}$ territory each year.

This is, however, significant part of land surveying in this country, but it does not cover everything. There exist both great land-surveying companies with a wide offer of services and products acting on the whole state territory and small land surveying companies specialized - for instance - on survey sketches and acting only on a limited territory. There are construction companies with their special needs for high accuracy while laying out and monitoring buildings. There are utility companies with their specific needs for documentation in technical maps, today on the base of GIS, for professionals as well as for common users. There is public administration demanding updated and precise information about the territory for its decisions. All these diverse ideas and professional needs should be satisfied. Universities ought to strive to offer skilled graduates equipped with the necessary knowledge and skills and above all with the ability to proceed further in their personal development. This task is definitely not simple, because the educational process cannot omit other even more important aspects and universities have to develop also the language skills or economic awareness of students and last, but not least, to address the general personal development including the ability to present the results of their work.

Well, I hope this conference will inspire many new ideas which will enrich the education of graduates of land surveying and geomatics and even influence lifelong learning. We all employers and employees as well as our customers, business partners and universities - will benefit from such a development in the future. I hope, that you find the Prague atmosphere hospitable and inspiring. At the Czech Technical University in Prague - such discussions have been held for 300 years and without such debates no University would be able to fulfill its mission.

I wish your conference success once again.

Thank you for your attention. 
Karel Večeře, Scientia Est Potentia ${ }^{1}$ - FIG Commission 2 Symposium, Prague, Czech Republic, 7-9 June 2007

\footnotetext{
${ }^{1}$ http://geoinformatics.fsv.cvut.cz/wiki/index.php/Scientia_Est_Potentia
} 